\title{
Teacher and Textbook in the Changing World
}

\author{
Aleksandra I. Artyukhina* (a), Svetlana V. Tretyak (b), Vasily V. Velikanov (c), \\ Nina V. Ivanova $(d)$
}

(a) Volgograd State Medical University, 400131, Volgograd, Russian Federation, 1, Pavshikh Bortsov sq.

(b) Volgograd State Medical University, 400131, Volgograd, Russian Federation, 1, Pavshikh Bortsov sq.

(c)Volgograd State Technical University, 400005, Volgograd, Russian Federation, 28, Lenin avenue

(d) Volgograd State Technical University, 400005, Volgograd, Russian Federation, 28, Lenin avenue; Volgograd State Agrarian University, 400002, Volgograd, Russian Federation, 26, Universitetsky pr.

Alexandraiart2591@gmail.com

\begin{abstract}
The topicality of the research is substantiated by the transformations in higher education, leading to changes in professional activity of teachers, working in the conditions of constantly updating educational environment and the lack of modern textbooks satisfying the educational needs of students, postgraduate students and university teaching staff members. The purpose of the article is to reveal the criteria for development and the requirements for the textbooks intended for students of universities and for university instructors in the process of continuing professional education, as well as to propose new approaches to involving students in active use of textbooks. The leading approach to the analysis of the stated problem was the competence-activity approach. The tendency of changing students' views on the "ideal" textbook at the under-and post-graduate level is revealed. A promising technique of students ' work with textbooks, additional to the traditional types of work, is described. The methodology of the organization of learners' activities with a textbook in the unity of specific professional and humanitarian contexts, as well as the rationale for designing the content of a textbook at the levels of subject knowledge and experience mastering are presented. The examples of publications based on different approaches are given - an electronic textbook with a fundamental representation of educational technologies and a textbook developed on the basis of the idea of a class designer. The presented results can be used for theoretical analysis of the methodology of textbooks development and for the improvement of textbook compiling practices.

Keywords: teacher; textbook; higher medical education, humanitarian approach
\end{abstract}

(C) 2021 Aleksandra I. Artyukhina, Svetlana V. Tretyak, Vasily V. Velikanov, Nina V. Ivanova This is an open access article distributed under the terms of the Creative Commons Attribution License (CC BY 4.0), which permits unrestricted use, distribution, and reproduction in any medium, provided the original author and source are credited.

Published by Moscow City University and peer-reviewed under responsibility of TSNI-2021 (Textbook: Focus on Students' National Identity)

\section{Introduction}


The world in the XXI century is changing rapidly due to globalization, socio-economic and geopolitical changes, the avalanching development of production and digital technologies as a result of the constantly changing economic, financial, and information needs of the market, and today - the spread of a new coronavirus pandemic. In the XXI century, the world pays special attention to human resources, since the success and competitiveness of any state is now determined by the quality, professional competence, and creativity of its citizens. The famous statement of R. W. Emerson, who believed that the real level of civilization is vivid not through the population census, the size of the cities or the harvest, but in the quality of the person that the country produces, today characterizes the reason for the ongoing transformations in the educational system, including medical schools.

The answer to the challenges of the time is the ongoing transformation of the higher professional schools in Russia and abroad. Sufficient changes in higher professional education in Russia are caused by a large set of reasons, to name a few of them: integration into the European and global educational space; strengthening of international cooperation, increasing academic mobility of teachers and students; transition from the knowledge paradigm to the personality-oriented paradigm; bringing to the fore the competenceactivity approach, aimed at strengthening the practical training of students; digital transformation of education; implementation of the principles of continuing education and the emergence of new types of educational institutions for non-formal education (Platonova, Kuz'minov, \& Frumin 2019).

At the practical level the changes mentioned above pose the challenges to university instructors. They are to construct classes and provide the students with the opportunities of active involvement into the educational process being a subject of learning, when students themselves consciously and actively develop the strategies and perspectives of the profession acquisition. It implies:

- introduction of technologies and strategies aimed at involvement of students in scientific research (research-based learning);

- expansion of differentiation and individualization of the educational process, that can be provided by the courses of the variable part of educational programs and elective disciplines, through which the students get the many-sided image of their future profession in a great number of its aspects (event-based education);

- balance between meeting the educational needs of gifted students and attention to the "average" student through identification and development of students ' personal abilities and experience; 
- development of specific educational content able to transmit both the accumulated professional knowledge and the traditional cultural, moral and professional values - compassion, humanism, mercifulness, benevolence, selfless service to the population and a lot more;

- reflection of the values in the content of the textbooks, manuals and other teaching material.

The last aspect presents considerable difficulties to the teaching community and becomes of the most pressing theoretical and practical issues. The requirements to the teaching material and the image of an "ideal" textbook changed greatly. Nowadays the textbooks and manuals should equip the future specialists with knowledge, the scope of approaches to prevention, treatment and rehabilitation procedures, and also with the opportunities of experience development. The graduates of the higher medical and pharmaceutical school of Russia are called upon to preserve the health of the nation, so the state pays great attention to the training of doctors. Professional training of personnel for healthcare in Russia is subject to the state program of the Russian Federation "Development of Healthcare" (January 1, 2018). The project "Provision of healthcare with qualified specialists" is presented as one of the priorities. Important tasks have been set in the field of personnel training for the healthcare system - to provide the transition from routine training to creative development of intelligence, training of professional management; to equip the learners with the innovative diagnostic, therapeutic and organizational technologies; to develop a large set of competences to meet the growing expectations of patients (Artyukhina, A. I., Mandrikov, V. B., Chizhova, V. M., Chumakov V. I., Bondarenko, E. V., Vahtina, E. A., \& Sopit, T. P., 2019). The higher medical schools implement the principles of training, identified as the principles of "training of the future": Learning Design Informed by Analytics, Flipped Learning, Bring-Your-Own-Devices, Learning to Learn, Learning through Storytelling, Threshold Concepts, Bricolage (Johnson, Adams Becker, Estrada \& Freeman, 2014; Majewska, 2018). But all these innovative pedagogical techniques should be mastered both by instructors and learners, which implies the compiling of teaching materials. A teacher (a university instructor) and teaching material are always in the center of any changes in the higher medical school. These changes (humanization and humanitarization of education, implementation of simulation, e-learning, etc.) are aimed at training competent, mobile, competitive in the labor market, highly qualified specialists-doctors and pharmacists (Malyutina \&Lonskaya, 2016).

The urgency of the issue can be further substantiated by the lack of medical textbooks incorporating the clinical aspects and the variety of social, psychological and other factors contributing to the health-related problem. The range of humanitarian problems of the doctor's work is huge and unique - the preservation and development of people's health in terms of interaction with the natural, cultural and social environment; relationships in various systems (doctor-patient, doctor-doctor, etc.); the influence of cultural and socio- 
economic factors on a person's attitude to their own health; social and ethical responsibility for the quality and sustainability of the obtained results (Zhigadlo, Rybakova \& Osadchuk, 2018). These aspects can't be fully perceived in the course of humanitarian subjects only. The content of every specialized medical course should be enriched with the humanitarian component and supported by corresponding teaching material.

\section{Purpose and objectives of the study}

Theoretical analysis of the current state of the problem using available literature sources and our own pedagogical experience allowed us to formulate the purpose of the study. The main aim of the paper is to reveal the criteria for development and the requirements for the textbooks intended for students of medical universities and for university instructors in the process of continuing professional training.

Considering the purpose, the following tasks should be solved: to study and describe the core components of the educational content to be presented in medical school textbooks and other teaching materials; to characterize the specific features of textbooks for medical university students and instructors taking continuing training courses to improve their professional and pedagogical competencies in order to satisfy the needs of the new pedagogical reality; to propose new approaches to involving students in active use of textbooks.

Another problem field is the study of the interaction of a university teacher with a textbook, which as we believe includes: assessment of the textbook content and purposeful selection of a textbook that assures the development of the required competences; choice of relevant pedagogical methods and techniques to represent the content and to involve the students in active use of the textbook.

\section{Literature review}

Traditionally, it is considered that the main task of the textbook is to help the student and the teacher to organize the educational process, which will be focused on the creation of educational products corresponding to the field of study. But the educational product can be and even should me broader than the subject field. The content of a textbook should provide opportunities for the development of competencies and experience not only in the subject area, but also in adjacent spheres. That's why we can't but agree with A. V. Khutorsky that a modern university needs a modern type of textbook, regardless of whether such a textbook is printed or electronic (Khutorskoy, 2020). The structure of the textbook is considered as the 
main factor of the learning process intensification. Let's consider the main options for structuring the content of a textbook.

The first variant is a programmed textbook, the key didactic advantage of which is the optimal combination of information and assessment elements, which allows them to be combined into a single whole (Gurkovskaya, Petrenko \& Tarakanova, 2019).

The second variant is didactic foliation (layering) of a textbook content. The authors of this method correlated the competence-based and information-activity models of the educational process that allowed a layered designing of the educational content on the basis of didactic foliation. This is a structure that divides the entire content of the textbook into disjoint subsets in accordance with independent criteria for foliation that implement certain learning goals. Independent criteria for layering can be understood as indicators that reflect the logic of presenting the subject information and the logic of its mastering. They provide horizontal and vertical layering of the course material (Ovchinnikova \& Frolov, 2016).

The third variant is a traditional textbook but designed in terms of a competence-based approach implementing the idea of practical, productive development of an academic discipline. The students themselves choose between various types of tasks, activities and approaches to the learning process organization or propose their own (Khutorskoy, 2020). The author, relying on the key general cultural competencies and professional competencies, considers a textbook to be an organizer of students 'activities through a system of tasks leading to the creation of students' own educational products - judgments, models, solutions, definitions, projects, which makes the fundamental difference between a competenceoriented textbook and a knowledge-oriented textbook. The textbook also contains a reasoned presentation of the key issues of the course, a meta-subject component, and recommendations for stimulating students ' reflection, i.e. tools for organizing different types of student activities. It also implements a studentcentered approach to learning and contains the elements for evaluation of the educational outcomes, representing three subsystems. They are a rating system for assessment of the product created by a student while performing a task, a rating system for assessment of activities performed by the student and a rating system for competencies assessment. The three-level system includes the methods of reflection, questioning and testing. One more example of a modern university textbook integrated with a practical tutorial is the textbook "Pedagogy of higher education in the modern world: a textbook and a practical tutorial for universities" (Taratuhina \& Avdeeva, 2020).

The emergence and updating of information and communication technologies in the educational process of higher education, massive open online learning contributed to the creation of electronic textbooks. The 
situation of the COVID-19 coronavirus pandemic, which led to distance learning of students, has actualized the problem of developing electronic textbooks. Since the understanding of the teaching material is fundamentally important for learning, the interest of scientists was focused on the study of differences in comprehension of printed and digital information, a cognitive approach to reading comprehension (Singer \& Alexander, 2017; Willingham, 2017; Wolf, 2016). Researchers work out the design of an electronic version of the textbook, considering the principles of an individual approach, updating, interactivity, clarity, accessibility, time saving, efficiency of search and the possibility of its application as an informativeeducational environment (resource) for independent work of students, using TurboSite (as an example) (Ivanova, 2019). The scenario approach to the construction of an electronic textbook with variability of the scenarios of its use in the educational process is of particular interest. The scenarios depend on the type of academic subject determined by the leading content component, on the one hand, and on the category of users of electronic textbooks - students, teachers or administrators, on the other hand. The roles of the categories of users are different, and the author gives examples of the corresponding scenarios (Martyushova, 2017). The development of evaluation criteria for comparing printed and electronic textbooks also attracts the attention of researchers (Ivić, 2019)

\section{Methodology}

The empirical base of the research is Volgograd State Medical University. The leading approach to the problem study is competence-activity approach. The methods of generalization, comparison, observation, systemic analysis, data grouping and theoretical cognition were utilized by the researchers. It is not uncommon for specialized higher educational establishments to put greater emphasis on special subjects. These courses are traditionally better equipped technologically, materially and in any other sense. A vast majority of special textbooks, practical tutorials, digital educational resources and technologies are at the disposal of the students. Humanitarian subjects being the minors are less provided with teaching materials. Besides, they are not intended for a specific professional community, but rather for a generalized university student. Here we deal with two difficulties at once. The first is the lack of personal interest to humanitarian subjects in the majority of medical university students. These subjects are left outside the sphere of professional, hence, personal value. They are included into the curriculum of the junior years, when the students have little or almost no idea of the scope of humanitarian problems they will deal with in future. It explains low involvement of students into the learning process. We consider it to be the first hardship to overcome. The second difficulty is the choice of textbooks and methodological issues of their use in the educational process. To reveal favourable characteristics and the criteria for the choice of a relevant textbook, several significant aspects were considered. 
The content of a textbook should present the unity of humanitarian and special (professional) components. It implies the need for the content able to develop students' ideas (beliefs, notions) about the importance of the humanitarian component of professional education and the value attitude to humanitarian knowledge, not only at the cognitive, but also at the behavioral levels. The level of self-determination, reflection, dialogicality as a style of thinking, readiness to perceive the plurality of truth and conscious attitude to the study of humanitarian subjects on the level of development of mechanisms and experience of goal-setting activity also have a significant impact on the process of mastering humanitarian knowledge. If education in the context of the unity of humanitarian and subject knowledge is not implemented in the content of the textbook, medical students are not able to assess the importance of the humanitarian component of education for achieving professional and personal goals. Therefore, they do not see the value and significance of humanitarian knowledge.

The second aspect that characterizes a favored textbook is the reflection of the most vital social, cultural and professional values - compassion, humanism, mercifulness, benevolence, selfless service to the population. The essential characteristic of humanitarian knowledge is its dialogic nature, readiness for understanding through cognition and communication. If we remove one link from this chain communication, dialogue - cognition becomes monologic, which is more characteristic of exact and natural sciences. To develop a humanitarian-oriented personality of the future doctor, to actualize his general cultural and general professional competencies, the content of the textbook and the presentation of educational material, should create environment (educational situation, event) for a "meeting, collision" of the future doctor with humanitarian problems of professional activity. Clarifying the differences between natural science approaches and humanitarian approaches is important for future doctors for the formation of an image of a patient - whether to estimate it as an object of the treatment process or as a subject, fighting together with a doctor against a disease. The former traditional approach to teaching used to unconsciously create the illusion of the possibility of treating a human by treating his body only, thereby identifying the patient with a sick body, and promoting natural science approach to the study of a human. This approach is erroneous and leads to dehumanization of medicine, as soon as it deforms the morality of future physicians and generates incorrect image of a patient.

The next specific feature of humanitarian knowledge that should be reflected in the content of a textbook is the uniqueness of the results. They cannot be represented in the form of initially set didactic units, which can be "measured", evaluated by quantitative indicators. This approach corresponds to the exact and natural sciences, which seek to identify general laws, trends, uniformity. The very process of cognition through personally meaningful experiences and correlation with personal experience is a goal and a result in itself, as the students form a picture of the world and a picture of the profession (Tret'yak, 2020). 


\section{Results}

The first task of our research was to study and describe the core components of the educational content to be presented in medical school textbooks and other teaching materials. As it was already said, a favoured textbook should present the unity of humanitarian and special (professional) components. Its content should transmit both the accumulated professional knowledge and the traditional cultural, moral and professional values able to develop students' self-determination, dialogicality as a style of thinking, experience of goal-setting activity and readiness to perceive the plurality of truth.

We believe that the content aspect of a textbook compiling implies the construction of the scientific content at two levels: the level of subject knowledge (including the humanities) and the level of acquired experience:

- experience of value-oriented activity - analysis and assessment of educational content, its value aspects from the point of view of their social, professional and personal significance;

- the experience of educational activities, which allows to effectively and independently master the content of the course - setting goals for cognitive activities, finding ways to achieve the goals;

- experience in activating humanitarian knowledge (conducting humanitarian expertise as an assessment of social, ethical, legal and other aspects of professional actions).

The second task was to characterize the specific features of textbooks for medical university students and instructors, taking continuing training courses to improve their professional and pedagogical competencies in order to satisfy the needs of the new pedagogical reality. The search for the most advantageous textbook (manual) for teaching is commonly based on the notion of a number of specific features that distinguish the variety of teaching resources.

It was empirically found out that the students' notion of an "ideal" textbook has a lot of aspects. It heavily depends on the leading motives of study, aims, interests and specifics of cognitive processes. And still there are a lot of common requirements and preferences. The majority of students believe that the textbook should be: interesting, clear, concise, interactive, accessible in electronic databases and in the university library. It should contain the tasks for self-check at the end of the paragraph as a feedback option and reflect the specifics of the future profession. The format of a practical manual (tutorial) was considered advantageous. But there were a number of students who emphasized the idea of adequate amount of information, knowledge of which will provide good rating results in the finals. It demonstrates the fact 
that for these students, knowledge is not yet fully integrated into the system of professionally and personally significant values, and the motives for its development are often external. The quantitative presentation of the results wasn't implied by the logics of the research as there would be a great number of variables - level of education, specialization, motives of study, personal interests and former experience of dealing with different types of textbooks and a lot more.

The third task was to propose new approaches to involving students in active use of textbooks. We have supplemented the traditional types of students' work with textbooks with a new methodological technique. Before starting to study a new topic, a group of students given a task to compare the presentation of educational material in different textbooks, giving a justification for the advantages and disadvantages of each textbook and providing recommendations to their friends on the choice of a textbook.

When developing a project textbook we focused on actualizing personal and professional interest of students. The task was far beyond acquiring professionally valued knowledge. We assume that any textbook in clinical disciplines should contain the material for problem reasoning and the values conflict. These can be contradictions between the mastered methods of natural science and the spectrum of humanitarian problems that cannot be solved by these methods; contradictions between universal humanistic values, reflected in the humanities, and the desire to achieve material well-being and social recognition by any means. Students conduct factual analysis of situations and evaluative analysis of the motives that guide people's actions. To form their own position, students need to consider various professional problems and apply knowledge and personal experience in many areas. This contributes to the establishment of interdisciplinary connections of the subjects of the university program, the formation of a holistic picture of humanitarian problems of a professional nature and the readiness to be guided by universal values and ideals when solving them.

Improving the university teachers' competences in pedagogy and methodology of education through continuous training is the basis for ensuring high-quality education (Kyndt, Gijbels, Grosemans \& Donche, 2016). Postgraduate students and medical professional taking the continuing training courses emphasized the lack of textbooks for medical specialists involved in teaching. So we compiled a project textbook based on different approaches. The textbook "Educational technologies in higher medical school" is presented in digital format to be used in classroom work with graduate students and in the system of advanced training of medical university instructors. The textbook presents modern educational technologies (in terms of theory and practical application) that can be used in the educational process of the higher medical school. The authors' team had no aim to describe every educational technology, but focused on introducing techniques that have proven successful, but are not actively used in medical universities, or have recently 
appeared and are not well known. The choice of educational technologies considered in the textbook was determined by the educational need of the postgraduate students and listeners of the continuing training courses students of the Volgograd State Medical University. Educational needs were identified in the course of an entrance survey (Artyukhina, Mandrikov, V. B., Chizhova, V. M., Chumakov V. I., Bondarenko, E. V., Vahtina, E. A., \& Sopit, T. P., 2019). This textbook can also be used as a practical class constructor. The combination of techniques may serve as a designer kit that allows projecting classes with a varied set of didactic aims, objectives, targeted student group and the level of training (Artyuhina \& Chumakov, 2017).

\section{Discussions}

The sphere of higher education is constantly changing and the university instructors are also changing to improve their competences in order to meet the requirements of professional standards, to satisfy the needs of the healthcare services consumers and to meet the increasing requirements for the personal and professional qualities of medical specialists.

Teachers and university instructors, no matter how experienced and innovative they are, always use a textbook as a pedagogical tool. There are different aspects a teacher's interaction with a textbook: the purposeful choice of textbooks (manuals) for a particular subject; the choice of techniques to work with the textbook and to involve the students in learning activities; the use of the textbook to improve their own psychological and pedagogical skills; compiling a textbook. The revealed requirements for university textbook and differences in approaches to their development leave a number of unresolved issues. The question of the content of an ideal textbook for students remains controversial. The discrepancy is observed even in the views of students and residents - from the most concise subject presentation to the voluminous fundamental one.

\section{Conclusion}

The search for new modern tools for textbooks improvement, their analysis, testing, and introduction into the pedagogical practice of higher education are ongoing processes. The pedagogical activities of any university teaching staff member rely on high-quality textbooks which aid to the development of a welltrained specialist, flexible in his approaches, able to meet the changing requirements and integrated into the system of continuous professional training. Improvement of textbooks for medical students implies the introduction of a humanitarian component into the content as one of the options. A textbook for improving professional and pedagogical qualifications should be focused on the educational needs of teachers, and the 
creation of such a textbook is a manifestation of the teacher's superior skill in a changing the future world. The presented results can be used to develop textbooks for higher medical educational establishments and improve the learning outcomes, both professionally and personally valuable.

\section{References}

Artyuhina, A. I., Mandrikov, V. B., Chizhova, V. M., Chumakov V. I., Bondarenko, E. V., Vahtina, E. A., \& Sopit, T. P. (2019) Obrazovatel'nye tekhnologii v vysshej medicinskoj shkole: uchebnik [Educational technologies in higher medical school: textbook], Volgograd: VolgSMU Publishers

Artyuhina, A. I., \& Chumakov, V. I. (2017) Prakticheskoe zanyatie v vysshej medicinskoj shkole: uchebnoe posobie [Practical class in high medical school: manual]. Volgograd, VolgSMU Publishers

Gurkovskaya, E. A., Petrenko, A. A., \& Tarakanova, V. V. (2019) Struktura uchebnoj literatury kak glavnyj faktor intensifikacii processa obucheniya [The structure of educational literature - the main factor of the intensification of the learning process]. Municipal'noe obrazovanie: innovacii i eksperiment [Municipal education: innovation and experiment], 6 (69), 58-66.

Ivanova, D. V. (2019) Sozdanie elektronnyh uchebnikov v programme TurboSite [Development of electronic textbook in the program TurboSite]. Aktual'nye problemy metodiki obucheniya informatike $i$ matematike $v$ sovremennoj shkole. Materialy mezhdunarodnoj nauchno-prakticheskoj internetkonferencii [Urgent issues of the methodology of informatics and mathematics teaching in modern school. Proceedings of international scientific practical Internet conference], Moscow, MPGU Publishers, 617-620.

Ivić, I. (2019) Printed and Digital Media: Printed and Digital Textbooks. CEPS Journal, 9/3, 25-50

Johnson, L., Adams Becker, S., Estrada, V. \& Freeman, A. (2014). NMC Horizon Report: 2014 K-12 Edition. Austin, Texas: The New Media Consortium. Retrieved from https://www.learntechlib.org/p/147472/

Khutorskoy, A. V. (2020). Struktura i soderzhanie kompetentnostnogo uchebnika dlya vuza [Structure and content of the competent textbook for the university]. Vysshee obrazovanie segodnya [Higher education today], 1, 8-13.

Kyndt, E., Gijbels, D., Grosemans, I., \& Donche, V. (2016). Teachers' everyday professional development. Review of educational research, 86/4, 1111-1150. Retrieved from DOI: 
http://dx.doi.org/10.3102/0034654315627864

Majewska, K. (2018). Modern educational tools in the teacher's work. The New Educational Review, 51 $1,125-135$

Malyutina, T. V., \& Lonskaya L. V. (2016) Soderzhanie komponentov professional'no-pedagogicheskoj deyatel'nosti prepodavatelya medicinskogo vuza [Content of professionally pedagogical activity components of a medical high school teacher]. Sovremennye problemy nauki i obrazovaniya [Modern problems of science and education]. Retrieved from URL: http://scienceeducation.ru/ru/article/view?id=25691

Martyushova, Ya. G. (2017) Scenarnyj podhod k razrabotke i ispol'zovaniyu elektronnogo uchebnika v vuze [Scenario approach to the development and use of learning management system in universities]. Psihologicheskaya nauka i obrazovanie [Psychological science and education], 22/6, 45-55.

Ovchinnikova, K. R., \& Frolov, Yu. V. (2016) Uchebnik v kontekste kompetentnostno-professional'noj modeli vypusknika vuza [The textbook in the context of competence-based and professional model of the university graduate]. Vysshee obrazovanie segodnja [the Higher education today]. 1, 42-48.

Platonova, D. P., Kuz'minov, Ya. I., \& Frumin I.D. (Eds.). (2019). Universitety na pereput'e: vysshee obrazovanie $v$ Rossii [Universities at the crossroads: higher education in Russia]. Moscow: HSE Publishing House

Singer, L. T., \& Alexander, P. (2017). Reading on paper and digitally: What the past decades of empirical research reveal. Review of Educational Research, 87(6), 1007-1041.

Taratuhina, Yu. V., \& Avdeeva Z. K. (2020). Pedagogika vysshej shkoly v sovremennom mire: uchebnik i praktikum dlya vuzov [Pedagogy of higher school in modern world: a textbook and a practical course]. Moscow, Urait Publishers

Tret'yak, S. V. (2020). Osobennosti gumanitarnogo poznaniya i ih otrazhenie v metodologii organizacii uchebnogo processa $\mathrm{v}$ medvuze [Features of humanitarian cognition and their reflection in the methodology of the educational process in medical schools]. Razmyshleniya o CHeloveke: kollektivnaya monografiya [Reflections on a human: collective monograph], Volgograd, 173-180.

Willingham, D. T. (2017). The reading mind: A cognitive approach to understanding how the mind reads. San Francisco, CA: Jossey-Bass. 
Wolf, M. (2016). Reader, come home: The reading brain in a digital world. Sydney: Harper Collins.

Zhigadlo, A. P., Rybakova, N. N., \& Osadchuk, O. L. (2018). Proektirovanie soderzhaniya podgotovki pedagogov professional'nogo obucheniya $\mathrm{v}$ vuze na osnove kompetentnostnogo podhoda [Education content design for university vocational training teachers on the basis of competence approach]. Nauka o cheloveke: gumanitarnye issledovaniya [The science of person: humanitarian researches], 2 (32), 8693. 